OPEN ACCESS

Edited by:

Supaart Sirikantaramas, Chulalongkorn University, Thailand

Reviewed by: Costantino Paciolla, University of Bari Aldo Moro, Italy Osvaldo Failla

University of Milan, Italy

*Correspondence: Markus Rienth

markus.rienth@hes-so.ch

Specialty section: This article was submitted to

Plant Metabolism and

Chemodiversity,

a section of the journal

Frontiers in Plant Science

Received: 30 May 2021 Accepted: 01 November 2021 Published: 08 December 2021

Citation:

Rienth M, Vigneron N, Walker RP,

Castellarin SD, Sweetman C, Burbidge $C A$, Bonghi $C$,

Famiani F and Darriet P (2021) Modifications of Grapevine Berry Composition Induced by Main Viral and Fungal Pathogens in a Climate

Change Scenario.

Front. Plant Sci. 12:717223. doi: 10.3389/fpls.2021.717223

\section{Modifications of Grapevine Berry Composition Induced by Main Viral and Fungal Pathogens in a Climate Change Scenario}

\author{
Markus Rienth ${ }^{1 *}$, Nicolas Vigneron ${ }^{1}$, Robert P. Walker ${ }^{2}$, Simone Diego Castellarin ${ }^{3}$, \\ Crystal Sweetman ${ }^{4}$, Crista A. Burbidge ${ }^{5}$, Claudio Bonghi ${ }^{6}$, Franco Famiani ${ }^{2}$ and \\ Philippe Darriet ${ }^{7}$
}

'Changins College for Viticulture and Oenology, University of Sciences and Art Western Switzerland, Nyon, Switzerland, ${ }^{2}$ Dipartimento di Scienze Agrarie, Alimentari e Ambientali, Università degli Studi di Perugia, Perugia, Italy, ${ }^{3}$ Wine Research Centre, Faculty of Land and Food Systems, The University of British Columbia, Vancouver, BC, Canada, ${ }^{4}$ College of Science \& Engineering, Flinders University, Bedford Park, SA, Australia, ${ }^{5}$ School of Agriculture and Food, Commonwealth Scientific and Industrial Research Organization (CSIRO), Glen Osmond, SA, Australia, ${ }^{6}$ Department of Agronomy, Food, Natural Resources, Animals and Environment, University of Padova Agripolis, Legnaro, Italy, ${ }^{7}$ Univ. Bordeaux, Unité de recherche CEnologie EA 4577, USC 1366 INRAE, Institut des Sciences de la Vigne et du Vin, Villenave d'Ornon, France

The grapevine is subject to high number of fungal and viral diseases, which are responsible for important economic losses in the global wine sector every year. These pathogens deteriorate grapevine berry quality either directly via the modulation of fruit metabolic pathways and the production of endogenous compounds associated with bad taste and/ or flavor, or indirectly via their impact on vine physiology. The most common and devastating fungal diseases in viticulture are gray mold, downy mildew (DM), and powdery mildew (PM), caused, respectively by Botrytis cinerea, Plasmopara viticola, and Erysiphe necator. Whereas $B$. cinerea mainly infects and deteriorates the ripening fruit directly, deteriorations by DM and PM are mostly indirect via a reduction of photosynthetic leaf area. Nevertheless, mildews can also infect berries at certain developmental stages and directly alter fruit quality via the biosynthesis of unpleasant flavor compounds that impair ultimate wine quality. The grapevine is furthermore host of a wide range of viruses that reduce vine longevity, productivity and berry quality in different ways. The most widespread virusrelated diseases, that are known nowadays, are Grapevine Leafroll Disease (GLRD), Grapevine Fanleaf Disease (GFLD), and the more recently characterized grapevine red blotch disease (GRBD). Future climatic conditions are creating a more favorable environment for the proliferation of most virus-insect vectors, so the spread of virus-related diseases is expected to increase in most wine-growing regions. However, the impact of climate change on the evolution of fungal disease pressure will be variable and depending on region and pathogen, with mildews remaining certainly the major phytosanitary threat in 
most regions because their development rate is to a large extent temperature-driven. This paper aims to provide a review of published literature on most important grapevine fungal and viral pathogens and their impact on grape berry physiology and quality. Our overview of the published literature highlights gaps in our understanding of plant-pathogen interactions, which are valuable for conceiving future research programs dealing with the different pathogens and their impacts on grapevine berry quality and metabolism.

Keywords: grapevine, biotic stress, Plasmopara viticola, leafroll virus, fanleaf virus, Erysiphe necator, Botrytis cinerea

\section{INTRODUCTION}

The European grapevine Vitis vinifera L., by far the main Vitis species used for wine production in the world, is host of a multitude of biotic adveristies from insects and fungi to viruses and bacteria. Downy and powdery mildew (DM and PM) are the major fungal pathogens in most wine-growing regions worldwide. Because these two pathogens were accidentally imported into Europe from North America rather recently, at the end of the 19th century, their host, the European grapevine, did not co-evolve with them and consequently does not possess natural resistances against them. Thus, in order to guarantee sustainable yield and fruit quality, viticulture depends on relatively high amounts and frequency of pesticide application, compared to other agricultural crops. Because the grapevine has been propagated vegetatively for thousands of years, it is host of a very high number (currently $>80$ ) of graft- and vector-transmitted viral diseases that can cause important economic losses in all winegrowing regions worldwide, with the most important ones being grapevine fanleaf disease (GFLD), grapevine leafroll disease (GLRD), and the recently characterized grapevine red blotch disease (GRBD; Maliogka et al., 2015; Bragard et al., 2019; Fuchs, 2020).

The effects of global climate change on disease pressure are not unambiguous. Some models predict a decreasing fungal disease pressure and, consequently, as predicted by Zito et al. (2018) for PM and DM in the region of Burgundy, mainly due to lower precipitations during the growing season. Other modelling approaches show that the increase in temperature advances the outbreak time of diseases, such as DM, leading to more severe infections and more infection cycles, due to the polycyclic nature of the pathogen (Francesca et al., 2006; Bove et al., 2020). The higher temperature during the months of May and June create also a more favorable environment for mildew development, counterbalancing the effects of precipitation reductions, which alone would have diminished the disease pressure (Salinari et al., 2007). In any case, at the global level, mildews will very likely remain the major phytosanitary threat under future climatic conditions (Bois et al., 2017). In this context, the increasingly widespread use of single-site fungicides to control DM accelerated the development of $P$. viticola strain with resistance to most of the fungicide classes (Massi et al., 2021). The predicted increase in temperature caused by global warming is already leading to advances of the development of the grape berry moth whose larvae feed on ripening grape berries, thereby providing "entrygates" for B. cinerea infection (Reineke and Thiéry, 2016; Santos et al., 2020). This could consequently result in increasing berry mold infections if pest management strategies are not adapted. As for DM, rainfall and relative humidity are key factors for the onset of gray mold (Molitor et al., 2016). The increasing risk of mold infection could thus be counterbalanced by decreasing precipitations in some regions. Higher temperatures will also favor the development of insect vectors of bacterial and viral diseases and thus augments the spread of viral diseases in most growing regions (Bois et al., 2017). A better understanding of pathogen-host interactions is of upmost importance for elaborating efficient disease-management strategies in order to guarantee high quality and sustainable wine production in an evolving environment.

The lifecycle of the most common fungal diseases is wellcharacterized, as is their negative impact on grapevine physiology; yet, for most diseases, the molecular mechanisms that underpin the deterioration of berry quality remain to be elucidated. Recent advances in metabolomics led to the discovery of new odorous and non-odorous compounds produced either directly by pathogens or released by leaves or berries following infection (Darriet et al., 2002; Ky et al., 2012; Pons et al., 2018; de Ferron et al., 2020). These compounds can be linked to deleterious effects on wine quality. However, molecular data regarding the interactions between pathogens and the berry are scarce. Nevertheless, the rapid development and improvement of omic tools continuously increase our insights into plant-berry pathogen interactions (Blanco-Ulate et al., 2015, 2017; Rienth et al., 2019b; Ghaffari et al., 2020; Toffolatti et al., 2020; Pimentel et al., 2021). The first part of this review aims to summarize the most important and recent studies dealing with the effects of gray mold, PM, and DM on berry quality and metabolism. Subsequently, we review the literature describing the effects on berry physiology of the most important virus-related diseases, such as grapevine fanleaf, grapevine leafroll, and red blotch disease (a general overview of modulated metabolites is provided in Figure $\mathbf{1}$ and a more detailed summary of modulated compounds and transcripts in Supplementary Table 1). Although a major attention was paid on the effects on primary and secondary metabolism, we did not review the general biosynthetic pathways because this would have gone beyond the scope of the paper. For more detailed description of biosynthetic pathways in the grape berry we invite the reader to consult recent reviews on berry development and physiology (Conde et al., 2007; 


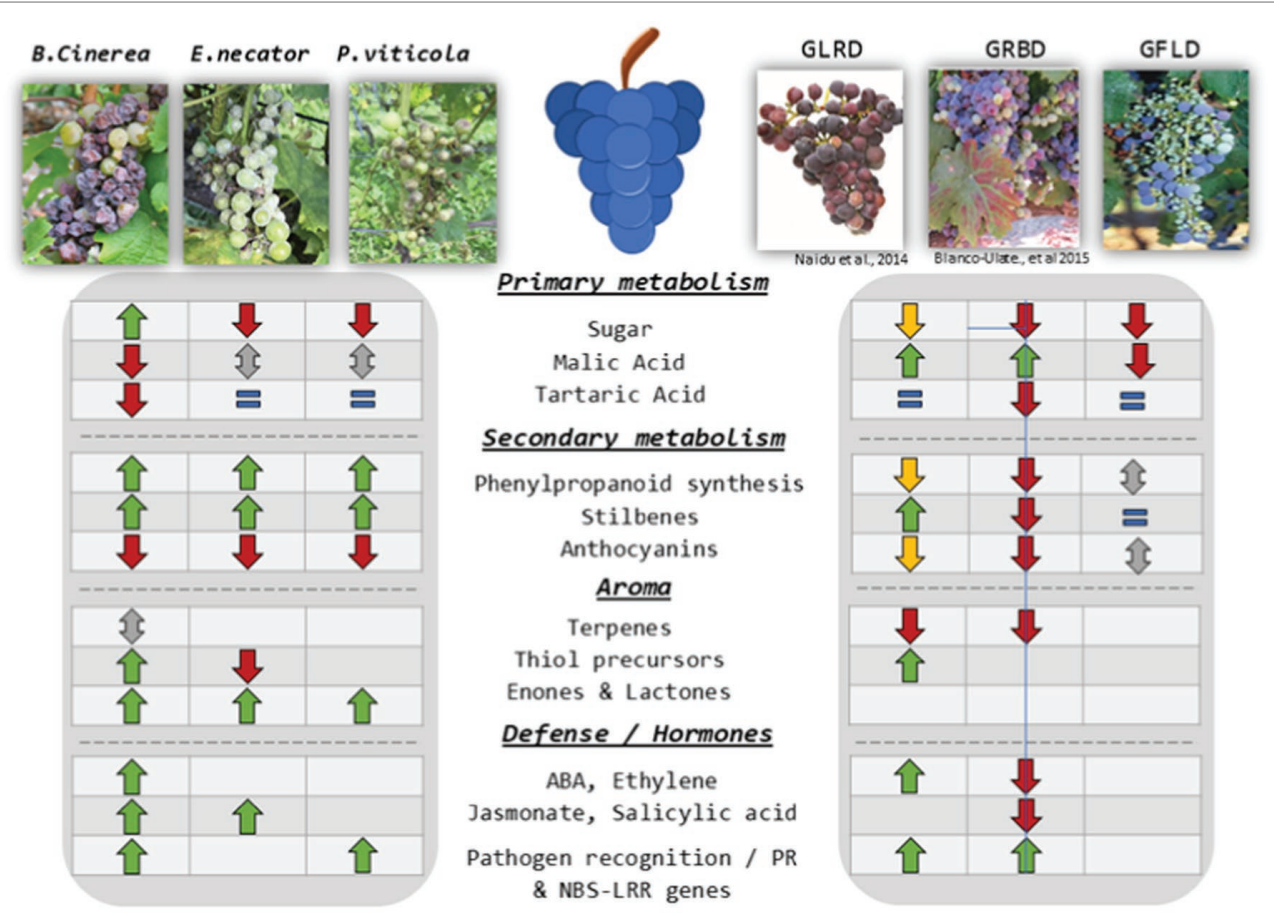

FIGURE 1 | General overview of most important metabolites and mechanisms modulated by the reviewed pathogens: $\downarrow$ : decrease; $\uparrow:$ increase; $\mathfrak{1}$ : opposed results reported; $\downarrow$ : decrease only in some studies likely due to sampling strategy, thus decrease putatively observed due to a delay in phenology; =: no differences.

Kuhn et al., 2013) as well as primary (Burbidge et al., 2021; Walker et al., 2021) and secondary metabolism (Azuma, 2018; Lin et al., 2019; Rienth et al., 2021).

\section{BOTRYTIS CINEREA}

Botrytis cinerea is among the most relevant berry-infecting fungal pathogens and is responsible for important reductions in yield and quality of grapes worldwide. Botrytis cinerea is responsible for both the so-called prejudicial gray mold and noble rot that will both be discussed in subsequent sections. Whether B. cinerea infection cause noble rot or gray mold is principally dependent on weather post-infection. Wet or humid conditions lead berries infected with $B$. cinerea to develop gray mold, whereas the development of noble rot requires moist nights and foggy mornings with dry and warm days.

\section{Noble Rot}

Noble rot is used to produce highly valued sweet dessert wines, such as Sauternes, Tokaji Aszu, and Amarone. The positive effects of noble rot are not only due to the concentration of sugar and aroma components through $B$. cinerea-induced water loss of the berry, but also from an enhanced synthesis of aromatic metabolites and their precursors, such as odorous lactones ( $\gamma$ and $\delta$ lactones) and their precursors (Miklósy and Kerényi, 2004; Tosi et al., 2012; Stamatopoulos et al., 2014; Lopez Pinar et al., 2017a,b; Stamatopoulos et al., 2018). In particular, this has been shown for S-conjugates of glutathione and cysteine, the precursors of varietal thiols reminiscent of citrus, grapefruit/passionfruit, or boxwood aroma. Their concentration can increase more than 100-fold upon $B$. cinerea infection (Sarrazin et al., 2007; Bailly et al., 2009; Thibon et al., 2009, 2011). The concomitant presence of S-conjugates of glutathione and cysteine in musts from infected berries as well as in botrytized berries highlights an activation of the glutathione biosynthetic pathways, a known strategy of plants as a general response to biotic (pathogenic attack) or abiotic stresses (injury, oxidative stress etc.; Hasanuzzaman et al., 2017). This has also been shown for grapevine leaves and berries exposed to cold and heat shock as well as UV irradiation (Kobayashi et al., 2011). Biosynthesis of S-conjugated amino acids and subsequent metabolites results from an increased release of reactive and toxic aldehydes, such as trans-2-hexenal reacting with glutathione to form glutathione S-conjugates, such as S-3-(hexan-1-ol)-glutathione, which in turn will be metabolized into S-conjugate cysteine and ultimately cleaved into sulfanylalcohols during fermentation by ß-lyase activity of Saccharomyces cerevisiae (Tominaga et al., 1998).

Other odorous volatile compounds, such as furanone, methional, and phenylacetaldehyde, have been found in botrytized berries (Kikuchi et al., 1983; Miklósy and Kerényi, 2004; Tosi et al., 2012; Stamatopoulos et al., 2014; Lopez Pinar et al., 2017a,b; Stamatopoulos et al., 2018). These compounds, with $\gamma$ and $\delta$ lactones and varietal thiols, can contribute in a desirable way to the flavor of sweet wines produced from noble rot-infected grapes (Schreier et al., 1976; Sarrazin et al., 2007; Tosi et al., 2012). Organic acids, such as tartaric and malic, are metabolized by the fungi and wines from botrytized berries have generally lower total acidity (Shimazu et al., 1984). 


\section{Gray Mold}

Gray mold can be very detrimental to fruit and wine quality due to the degradation of a number of grape berry components (Pallotta et al., 1998). In particular, phenolic compounds (anthocyanins, hydroxycinnamic acids, and flavanols) are oxidized by the polyphenol oxidase (laccase) activity of $B$. cinerea (Dubernet et al., 1977), which leads to quinones, that are highly reactive with glutathione and volatile odorous thiols. Ky et al. (2012) showed that all phenolic compounds (anthocyanins and proanthocyanidin monomers, dimers and trimers) decreased drastically in gray mold-infected grape skins as well as the mean degree of polymerization of the proanthocyanidin polymeric fraction.

Some aromatic components, like monoterpenes that play a major role in the aromas of Muscat grape cultivars and wines, are transformed into less odorous compounds (Boidron, 1978; Bock et al., 1986). Ethyl esters of fatty acids, which contribute to the fermentation aromas of wine, are hydrolyzed by the esterase activity of $B$. cinerea (Dubourdieu et al., 1983). Moreover, the development of gray mold, associated with abundant sporulation, as well as the presence of spores in the must, leads to the production of mushroom and earthy off-odors in the resulting wines (La Guerche et al., 2006; Lopez Pinar et al., 2017a,b). Compounds responsible for such off-odors have been identified as 1-octen-3-one, 1-octen-3-ol, 2-heptanol, and 2-octen-1-ol with mushroom notes, or 2 -methylisoborneol with strong earthy notes. Sometimes, a certain proportion of botrytized grapes $(<1-5 \%)$ are co-contaminated with other saprophytic fungi belonging to the genus Penicillium spp., particularly P. expansum, as well as Mucor spp., Trichotecium spp., Cladosporium spp., Aureobasidium spp., Alternaria spp., etc., which may develop inside the grape clusters, resulting in secondary rot with yellow, green, or pink shades. Their presence is generally favored by their ability to grow at lower temperatures than B. cinerea $\left(10-15^{\circ} \mathrm{C}\right)$. In this context, other off-odors may be detected in wines, associated with the formation of potent, malodorous compounds, particularly caused by the presence of Penicillium spp., in particular Penicillium expansum, and its production of (-)-geosmin (Darriet et al., 2000; La Guerche et al., 2006, 2007; Steel et al., 2013; Behr et al., 2014).

\section{Berry Transcriptomic Modulations by B. cinerea}

The four most recent whole-genome transcriptomic studies on B. cinerea-infected berries used either Microarrays (AgudeloRomero et al., 2015; Kelloniemi et al., 2015) or RNA-seq (Blanco-Ulate et al., 2015; Lovato et al., 2019a,b) to detect differentially expressed genes upon B. infection. Varieties, sampling- and infection protocols vary in all studies, making it difficult to draw general conclusions. Agudelo-Romero et al. (2015) and Blanco-Ulate et al. (2015) investigate gray mold infection on Semillon berries sampled at maturity $\left(23.9^{\circ}\right.$ Brix; Blanco-Ulate et al., 2015) and Trincadeira at two different stages of berry development (green berries: EL 33 and at véraison: EL 35; Agudelo-Romero et al., 2015). Both studies draw samples directly in situ. Kelloniemi et al. (2015) and Lovato et al. (2019b) studied noble rot on post-harvest-infected berries from Marselan berries cut at version and maturity (Kelloniemi et al., 2015) and on Muller-Thurgau and Garganega (Lovato et al., 2019b). Furthermore, the latter authors carried out a meta-analysis of transcriptomic data from all aforementioned studies on B. cinerea-infected grapes. They could identify only 17 commonly upregulated transcripts in all varieties and stages that were specific to $B$. cinera infection. When looking only at either gray mold or noble rot and only after véraison, commonly upregulated genes were found to be higher: 129 and 173, which seems still relatively low in comparison with other biotic (Rienth et al., 2019a) and abiotic stress (Rienth et al., 2014b; Lecourieux et al., 2017) transcriptomic studies. Obviously, this relatively low number of commonly regulated genes can, to some degree, be explained by the fact that gray mold and noble rot infections were compared from different varieties. However, it is very likely that the different, not very precisely defined and characterized berry sampling stages prevent the detection of more commonly genes modulated specifically by $B$. cinerea. It has been shown that a unprecise definition of berry sampling stages can biases biotic and abiotic stress to a high extent, mainly when studies include the stage of véraison (which is considered when $50 \%$ of berries change color), where a large transcriptomic reprogramming occurs (Terrier et al., 2005; Rienth et al., 2014a) within $24 \mathrm{~h}$ from green to soft (and colored) berries. Thus mixing green and colored berries from a cluster at véraison can introduce unquantifiable biases that could cover important transcriptomic regulations (Carbonell-Bejerano et al., 2016; Shahood et al., 2020).

Nevertheless when looking at different metabolic pathways one can summarize that in all studies, $B$. cinerea caused an induction of secondary metabolism. Notably, the phenylpropanoid pathway was generally highly activated, as indicated by the upregulation of R2R3-MYB, VviMYB5a/b transcription factors (TFs), known as key regulators of phenylpropanoids, and the downstream key genes involved in the production of flavonoids, such as chalcones, flavonols, and anthocyanins, procyanidins, lignin, and lignans (Blanco-Ulate et al., 2015; Lovato et al., 2019a,b).

In particular, the biosynthesis of stilbenes, major defense compounds (Gindro et al., 2012a), is highly activated upon B. cinerea infection, as highlighted by the induction of $V v M Y B 14$, VvSTSs and PAL expressions in samples of Lovato et al. (2019a,b) which was similar to that of berries sampled at the véraison stage by Kelloniemi et al. (2015). Interestingly, in the white cultivar Semillon, noble rot caused by B. cinerea induced the expression of transcriptional regulators normally expressed in the skins of red cultivars, including five R2R3-MYBs that regulate stilbene ( $V v M Y B 14, V v M Y B 15)$, proanthocyanidin (VvMYBPA1), and phenylpropanoid ( $V v M Y B C 2-L 1, V v M Y B 4 a)$ metabolism, as well as other potential regulators of ripening, such as $V v N A C 33, V v i N A C 60$, a zinc-finger transcription factor, a MYB transcription factor, and an $A P 2 / E R F$ transcription factor (Blanco-Ulate et al., 2015).

Transcriptomic data regarding volatile compounds biosynthesis highlight a cultivar-dependent response. For 
example, Blanco-Ulate et al. (2015) observed a general upregulation of several terpene synthases, $V v T P S$, in Sémillon botrytized berries, which was, however, not confirmed in Trincadeira (Agudelo-Romero et al., 2015) or Muller-Thurgau and Garganega (Lovato et al., 2019b), where terpene biosynthetic genes were generally downregulated by the infection. A further, more general physiological response of berry metabolism upon $B$. cinerea infection is the upregulation of oxidative stressrelated transcripts, abscisic acid, ethylene, jasmonate, and salicylate pathways, and genes encoding resistance (PR-genes; Agudelo-Romero et al., 2015; Coelho et al., 2019; Lovato et al., 2019b). Coelho et al. (2019) compared the hormonal response in Botrytis-infected berries of susceptible (Trincadeira) and resistant (Syrah) varieties and showed that high basal levels of salicylic acid (SA) and indoleacetic acid (IAA) at an early stage of ripening, together with activated SA and IAA metabolism and signaling seem to be important in providing a fast defense response leading to grape tolerance against $B$. cinerea.

Interestingly, a group of sugar transporter (SWEETs) seems to play an important role during $B$. cinerea infections as shown for the first time by Chong et al. (2014), who demonstrated an involvement of the grapevine SWEET transporter 4 (VvSWEET4). Moreover, they further showed that VvSWEET4 is a glucose transporter localized in the plasma membrane, which is upregulated by inducers of reactive oxygen species and virulence factors from necrotizing pathogens. This led authors to the hypothesis that stimulation of expression of a developmentally regulated glucose uniporter by reactive oxygen species production and extensive cell death after necrotrophic fungal infection could facilitate sugar acquisition from plant cells by the pathogen. Later, Breia et al. (2020b) highlighted the role of several other $V v S W E E T s$ in grapevine berries upon pathogen infections. Notably the mono- and disaccharide transporter VvSWEET7 was strongly upregulated during $B$. cinerea infection of grape berries. This induction may be caused by the pathogen itself to promote leakage of sugars into the apoplastic space for nutrition, or, as a defense-related process to improve sugar remobilization which can trigger signaling cascades that activate plant defense mechanisms. The same authors showed as well that grapevine's sucrose transporter Early-Response to Dehydration six-like 13 (VvERD6l13) was strongly upregulated in response to $B$. cinerea but as well by $E$. necator infection (Breia et al., 2020a).

As mentioned above, several studies report increased thiols, which correlate with the detoxification pathway and increased lactone content in wines and musts produced from B. cinereainfected grapes. Together with the upregulation of the phenylpropanoid, anthocyanin, stilbene, and terpene pathways, and with the induction of defense phytohormones pathway, this highlights a deep metabolic reprogramming as a plant defense mechanism against $B$. cinerea infection. However, transcriptomic studies are unambiguous regarding volatile synthesis. More studies including more varieties and precise definitions of berry sampling and infection protocols are required in the future to better characterize stage and variety dependent responses to $B$. cinerea which could also give more insight on genotypic plasticity of tolerance to infection of some varieties.

\section{DOWNY MILDEW - PLASMOPARA VITICOLA}

Downy mildew infections on leaves can cause important losses of leaf surface, and thus negatively affect carbon status at the vine level. This leads to ripening delay, slacking sugar accumulation, and malic acid respiration in berries. Therefore, grapes from vines with high infections of $P$. viticola have in general lower total soluble solids, less juice color, and higher acidity compared to fruits from healthy grapevines. DM can also infect berries at early stages, as well as the pre-bloom flowers, pedicel, and rachis (Kennelly et al., 2005). Mature berry infection is strongly restricted by ontogenic resistance due to the progressive modifications of stomata into lenticel at véraison (Gindro et al., 2012b). After véraison, sporulation can still be seen on pedicel and rachis with little to no consequence for berry quality. Probably, because of this almostabsence of DM infection after fruit set, few studies were conducted to understand the effect of $P$ viticola on berries. To understand the resistance mechanism of different cultivars, Gindro et al. (2012a) analyzed stilbene content in grape clusters of susceptible cultivars, such as Chasselas and Merlot, and resistant ones, such as Solaris and the hybrid 2091, after $P$. viticola infection. At the inflorescence stage (BBCH 53), in non inoculated conditions, susceptible cultivars presented a high basal content of piceid compared to the resistant ones. A shift in stilbene content occurred after inoculation for all cultivars. Upon infection susceptible cultivars showed a high accumulation of piceid while other stilbenes remained at lower concentrations. For Solaris, a higher accumulation of piceid, resveratrol, $\delta$ - and $\varepsilon$-viniferins, and pterostilbene compared to the control is observed. The 2091 hybrid showed a high accumulation of piceid and resveratrol and $\delta$-viniferin and a lower accumulation of $\varepsilon$-viniferin and pterostilbene. At later stage (end of flowering and berry pea-sized stages), a gradual diminution of stilbene content was observed, which was longer in susceptible cultivars, especially for Chasselas, with a high accumulation of resveratrol at the end of flowering that would later be metabolized at the berry pea-sized stage. Beside the stilbene-related plant defense response, DM berry infections modify the grape aroma profile. These modifications are associated with increased concentrations of lactones in wines, such as $\gamma$-octalactone, $\gamma$-nonalactone, and $\gamma$-decalactone, as well as a significant proportion of volatile compounds issued from unsaturated fatty acid degradation, such as (Z)-1,5heptadien-3-one and (Z)-1,5-octadien-3-one (geranium leaves descriptors; Pons et al., 2018). Furthermore, 3-methyl-2,4nonanedione (MND), a powerful $\beta$-diketone identified in prematurely aged red wines marked with an intense prune flavor, is more abundant in wines produced from grapes that include diseased berries. Finally, Merlot wines produced with increased levels of $P$. viticola-infected berries presented a higher intensity of the "cooked fruit" character and sometimes 
green nuances (Pons et al., 2018). Recently, Poitou et al. (2021) evidenced the impact of Methyl salicylate (MeSA), which induces plant defense resistance and is an odorous volatile compound presenting green nuances in wine. The latter authors could show that $P$. viticola-infected grapes had higher concentration of MeSA than healthy ones and showed that this aroma compound contributes in the expression of fresh green aromatic nuances in red wines, e.g., "pharmaceutical," "camphor," or "menthol" aromas. With the exception of stilbene-related defense mechanisms and lactone biosynthesis, the impact of $P$. viticola on berries remains elusive and requires deeper investigation, in particular from a molecular point of view.

\section{POWDERY MILDEW - ERYSIPHE NECATOR}

Together with DM, PM is the most important fungal disease infecting mainly grapevine leaves. Berry infections can occur during the green growth phase and are particularly detrimental to quality when they occur around fruit set. Berry infections during ripening are reported to occur until soluble solids levels reach $8^{\circ}$ Brix (Gadoury et al., 2003). As for DM, foliar infections can cause important losses of photosynthetic leaf area, which leads mainly to a delay in ripening, thus lower sugar concentration and higher acidity. When grape berries are directly infected with PM, they mostly show similar soluble solids content as healthy grapes but with significantly lower yields (Pool et al., 1984; Gadoury et al., 2001; Stummer et al., 2003, 2005; Calonnec et al., 2004; Pimentel et al., 2021). Contradictory results are reported concerning titratable acidity of infected berries, with some authors reporting an increase (Calonnec et al., 2004) and others a decrease (Lopez Pinar et al., 2016). Anthocyanin concentration was lower in Cabernet Sauvignon (Calonnec et al., 2004) and Sangiovese (Piermattei et al., 1999) in wines produced with PM-contaminated berries. Total phenolics, hydroxycinnamates, and flavonoids were higher in wines from infected grapes from the white cultivar Chardonnay (Stummer et al., 2003, 2005).

Studies about effects on aroma compounds are scarce. Calonnec et al. (2004) report a decrease of the thiol 3sulfanylhexan-1-ol (3SH) in Sauvignon blanc wines and high concentrations of lactones ( $\boldsymbol{\gamma}$-butyrolactone, $\boldsymbol{\gamma}$-dodecalactone, and $\gamma$-decalactone) similarly to what also observed in Riesling when berries were affected with PM (Lopez Pinar et al., 2017a,b).

Another important aspect of PM development on grapes concerns the presence of 1-octen-3-one (mushroom-like notes), (Z)-1,5-octadien-3-one (geranium leaf-like notes), phenylacetic acid (honey notes), and (R)-carvone (spearmint notes). The enone aroma-related compounds mentioned above generally diminish and sometimes disappear during winemaking, a phenomena related to the enzymatic reduction of main off-odors [1-octen-3-one, (Z)-1,5-octadien-3-one] to less odorant compounds [3-octanone, $(Z)$-5-octen-3-one] by enone reductase of Saccharomyces cerevisiae (Wanner and Tressl, 1998; Darriet et al., 2002).

Transcriptomic studies on PM infection of grapevine berries are scarce. Up to our knowledge, the only comprehensive metabolomic and whole-genome transcriptomic study on PM-infected berries was conducted on Grenache berries on developmental stages EL32 (green berry at bunch closer) and EL35 (véraison) by Pimentel et al. (2021). They report a strong indication of defensive mechanisms upon PM infection indicated by higher levels of jasmonates and salicylic acid together with the secretion of effectors related to effectortriggered susceptibility, such as PR1 genes and Enhanced disease susceptibility 1 (EDS 1). PM infection lead as well to an upregulation of carbohydrate-active enzymes, fatty acid and nitrogen uptake and the increase of metabolites, such as gallic, eicosanoic and docosanoic acids, and resveratrol, which could serve as potential metabolic biomarkers, that could be used to monitor the early stages of the infection (Pimentel et al., 2021). Furthermore, PM infection induced an activation of key phenylpropanoid pathway genes ( $P A L$, $\mathrm{C} 4 \mathrm{H}, 4 \mathrm{CL}, \mathrm{CHS}, \mathrm{F} 3 \mathrm{H}$ ) and accumulation of catechins, resveratrol and an overexpression of the respective transcripts, such as LAR/ANS and STSs. Anthocyanins transcripts (F3'5' $H$, F3'H,UFGT) were also found to be upregulated in early stages of berry development, which goes along with previous studies on Chardonnay (Stummer et al., 2003, 2005). These transcripts were particularly upregulated in the green berry (EL32) and correlated with higher anthocyanin content. This was however not significant anymore at EL35. Since anthocyanin accumulation starts at later stages after véraison a clear conclusion on the impact on anthocyanins at maturity cannot be drawn on the basis of these results.

Infection of berries with secondary fungi can be responsible not only for off flavors in grape and wine but also for high concentration of phytotoxin, such as ochratoxin A (OTA) or fumonisin B2 (FB2). Indeed, in an interesting study, it was seen that Negroamaro berries, infected with PM were significantly more susceptible to both Aspergillus niger and Aspergillus carbonarius colonization which produce FB2 and OTA (Cozzi et al., 2013).

\section{VIRUS INFECTIONS}

The present section will summarize the impact on berry composition of the most important viral diseases, GLRD, GFLD, as well as the recently discovered and described Grapevine red blotch and Pinot Gris virus (Sudarshana et al., 2015; Blanco-Ulate et al., 2017; Adiputra et al., 2018; Reynard et al., 2018; Cieniewicz et al., 2020).

In general, symptoms of virus infections in plants strongly vary according to genotype and, up to a great extent, to pedoclimatic conditions (Cretazzo et al., 2010). The symptoms differ as well between plant tissues, sometimes triggering completely opposite metabolic responses in berries (Vega et al., 2011) or leaves as was shown for GLRD (Perrone et al., 2017). 


\section{Grapevine Leafroll Disease}

Grapevine leafroll disease is considered the most widespread and devastating virus-associated disease. So far, nine serologically distinct virus types from the Closteroviridae family were associated with GLRD, named grapevine leafroll associated virus (GLRaV) types 1-9, with the most widespread ones being GLRaV-1 and GLRaV-3 (Maree et al., 2013; Velasco et al., 2014). GLRD causes important reductions in yield, vigor, and longevity of vines. It also delays fruit ripening, reduces sugar accumulation, and impairs fruit pigmentation (Guidoni et al., 1997; Maree et al., 2013; Naidu et al., 2014, 2015; Alabi et al., 2016). Decreases in anthocyanin and total flavonoid concentrations due to GLRD infections were related to the downregulation of anthocyaninrelated transcripts, such as $V v U F G T, V v M Y A B A 1$, and other phenylpropanoid genes, such as VvCHS, VvFLS1, and VvMYAPA1 (Vega et al., 2011; Vondras et al., 2021). Vega et al. (2011) also observed a viral repression of sugar transporters, which translated to lower sugar concentration in grapes. Interestingly, a study using a different berry sampling approach, which accounts for potential phenological shifts and intracluster berry heterogeneity, has demonstrated that the downregulation of genes belonging to primary and secondary metabolite pathways was mainly due to the berry phenological delay induced by GLRD infection and not to a direct effect of the viral infection (Rienth et al., 2019b; Ghaffari et al., 2020). In a very comprehensive study on Carbernet Franc over 2 years on different rootstocks, Vondras et al. (2021) observed a rootstock specific transcriptomic response of berries from GLRaV-infected vines. Latter authors observed the modulation of genes related to pathogen detection, for example NBS-LRR genes that confer resistance to powdery and downy mildew (DM) in grapevine (Riaz et al., 2011; Zini et al., 2019), as well as abscisic acid (ABA) signaling, phenylpropanoid biosynthesis, and cytoskeleton remodeling similar to previous studies of Vega et al. (2011) and Ghaffari et al. (2020). Interestingly the increase of ABA abundance in GLRD-infected berries (Vondras et al., 2021) was different than that observed for red blotch virus-infected berries, in which ABA abundance and NCED expression decrease in infected berries after véraison (BlancoUlate et al., 2017).

In leaves, some studies report a similar upregulation of defense-related genes and a concomitant accumulation of phenylpropanoids, such as resveratrol, which led to an enhanced resistance to downy mildew (Repetto et al., 2012). This highly interesting observation was somehow confirmed in a very elegant experiment, where authors transmitted GFLaV and grapevine rupestris stem pitting-associated virus (GRSPaV), by in vitro-grafting, to Nebbiolo and Chardonnay. Upon subsequent downy and powdery mildew infection, GFLV-infected plants showed a reduction in severity of the diseases caused by powdery and downy mildews in comparison to virus-free plants, which highlights a potential upregulation of plant innate immunity by GLRD infection (Gilardi et al., 2020).

\section{Grapevine Red Blotch Disease}

Grapevine red blotch disease is caused by the Grapevine red blotch-associated virus (GRBaV) and was discovered in 2008 in California. GRBD has recently become a major economic problem for the wine industry in many growing regions (Sudarshana et al., 2015; Adiputra et al., 2018; Reynard et al., 2018). GRBaV infections result in the appearance of red patches on the leaf blades, veins, and petioles in red grape varieties, whereas in white grape varieties, they cause irregular chlorotic areas on the leaf blades. Detrimental effects of red blotch disease are similar to GLRD. GRBaV affects berry physiology, causing uneven ripening, higher titratable acidity, and lower anthocyanin and sugar content (Girardello et al., 2019, 2020; Rumbaugh et al., 2021) putatively due to an impairment of carbon import into the berry (Martínez-Lüscher et al., 2019). Rumbaugh et al. (2021) observed a general decrease of fruity aroma compounds in Cabernet Sauvignon, mostly linked to a reduction of monoterpenes, such as limonene, $\beta$-myrcene, a-terpinene, geranial, and p-cymene. Higher titratable acidity has been attributed to lower acid respiration as shown by Pereira et al. (2021), who found 56\% higher malic acid and lower tartaric acid and phenolic compounds, such as the flavan3-ols, catechin, epicatechin and the flavonol quercetin-glucoside, in Cabernet Sauvignon infected with GRBaV.

Using RNA-seq for differential gene expression analysis, BlancoUlate et al. (2017) associated the GRBD-induced deterioration of grape quality with a downregulation of key genes of the phenylpropanoid pathway, which confirms aforementioned phenotypic observation. Furthermore, Blanco-Ulate et al. (2017) showed that GRBD disturbs berry development and induces stress responses by altering transcription factors (e.g., VviNACs, VviMYBs, and VviAP2-ERFs) and phytohormone networks causing an inhibition of the ripening process thus reducing color, flavor, and aroma compounds in berries.

\section{Grapevine Fanleaf Disease}

Grapevine fanleaf disease is one of the oldest known viral diseases of grapevines and has been found in all wine-growing regions around the world (Raski et al., 1983; Silva et al., 2017). GFLD has been reported to cause significant economic losses by reducing grape yield due to reduction of both cluster weight and berry weight, shortening the longevity of vines, and affecting fruit quality by decreasing the sugar content and titratable acidity (Raski et al., 1983). More detailed studies focusing on berry physiology and quality are not very numerous and often ambiguous. It has been shown that GFLD can also affect the anthocyanin levels in a cultivar-dependent manner. In the variety Manto Negro, GFLD reduced the anthocyanin level (Cretazzo et al., 2010), while in Schioppettino, an increase in anthocyanin content is observed and the relative proportions between di- and tri-hydroxylated or -methylated derivatives of anthocyanins seem to be affected via the upregulation of VviF3H1 and VviF3'H5 and downregulation of VviF3H (RupnikCigoj et al., 2018). Further studies on berries from GFLDinfected vines, including several developmental stages and cultivars, are utterly needed to better understand the effect on fruit quality of this widespread pathogen.

\section{New Emerging Virus-Associated Diseases}

Recently, several emerging viruses have been described (Cieniewicz et al., 2020), with the Pinot Gris Virus 
(Giampetruzzi et al., 2012) being the most threatening one. It is present in most wine-growing regions from North ( $\mathrm{Al}$ Rwahnih et al., 2016) and South America (Debat et al., 2020) to almost all the European countries, such as Italy (Gentili et al., 2017), Germany (Messmer et al., 2021), Spain (RuizGarcía and Olmos, 2017), and France (Renault-Spilmont et al., 2018). Although leaf symptoms are well-characterized, its impact on berry physiology has not yet been characterized in detail. The most important detrimental impact of Pinot Gris virus in viticulture is certainly the great reduction in yield, which can range between 66 and 85\%, as shown for Glera and Pinot Noir; however, it causes no significant alteration of fruit quality (Bertazzon et al., 2017).

\section{CONCLUSIONS}

The consequences of the most important fungal and viral diseases on grapevine performance, longevity, yield, and berry and wine quality are mostly well known. However, fundamental molecular studies, aiming to characterize the underpinning mechanisms involved in berry-pathogen interactions are scarce.

The most studied fungal pathogen, due to its multiplicity of host plants and fruits and its partly beneficial effects in the production of noble rot wines, is $B$. cinerea. For powdery and downy mildew and their rather indirect impact on berry development and quality, published studies focus almost entirely on the leaves' transcriptome and metabolome without considering berry development and metabolism. More molecular studies are therefore needed to gain more insight into the berry-pathogen interactions and to better characterize the negative effect of fungal pathogens on leaves as well as on berries. Furthermore, it would also be useful that future studies on berry-pathogen interactions focus more on a precise definition of the berry developmental stage and account for post-véraison berry heterogeneity (CarbonellBejerano et al., 2016; Rienth et al., 2021). This would improve comparability and thus yield better insights in molecular berry-pathogen interactions.

It would also be interesting from a growers' and scientific point of view to conduct more studies investigating the combined effects of fungal pathogens and their corresponding conventional or organic fungicides on berry composition and metabolism, as investigated by Rantsiou et al. (2020).

A growing concern in worldwide viticulture is grapevine trunk diseases, due to a lack of studies on them. Common consequences on berry quality seem to be lower sugars and

\section{REFERENCES}

Adiputra, J., Kesoju, S. R., and Naidu, R. A. (2018). The relative occurrence of grapevine leafroll-associated virus 3 and grapevine red blotch virus in Washington state vineyards. Plant Dis. 102, 2129-2135. doi: 10.1094/ PDIS-12-17-1962-RE

Agudelo-Romero, P., Erban, A., Rego, C., Carbonell-Bejerano, P., Nascimento, T., Sousa, L., et al. (2015). Transcriptome and metabolome reprogramming in Vitis vinifera cv. Trincadeira berries upon infection with Botrytis cinerea. J. Exp. Bot. 66, 1769-1785. doi: 10.1093/jxb/eru517 phenolic compounds, such as catechin, epicatechin, and anthocyanins (Lorrain et al., 2012; Fontaine et al., 2016). However, detailed physiological and omic studies are missing thus far. Viral diseases cause a global perturbation of the plant physiology with strong effects on primary and secondary metabolism that leads to interference with the ripening of berries. Characterization of the broad effect of viral disease is still in its infancy, but an increasing number of studies is being published using state-of-the-art molecular tools to provide valuable knowledge on plant/fruit-pathogen interactions. However, more coordinated efforts at genomic, transcriptomic, and metabolomic levels, in particular including epigenetics, should be deployed to understand and better characterize the differences among $V$. vinifera cultivars and their different responses to diseases. Furthermore, integrative studies comprising multiple simultaneous infections with different viral and fungal pathogens (Gilardi et al., 2020), even with abiotic stresses and multiple genotypes, should be considered in the future to better anticipate disease impact in a climate change scenario. A deeper understanding of defense response mechanisms in various $V$. vinifera as well as other Vitis spp. could help identify new resistance traits essential for improving breeding programs as well as for the development of biopesticides and biostimulants.

\section{AUTHOR CONTRIBUTIONS}

MR, SC, and PD devised the main body and structure and content of the manuscript. CS, CBu, CBo, NV, RW, and FF provided valuable ideas and corrections and triggered fruitful discussions via helpful comments. All authors contributed to the article and approved the submitted version.

\section{FUNDING}

The postdoc of NV was financed by the Swiss National Science Foundation (SNF) Project Grant IZCOZ0_189896.

\section{SUPPLEMENTARY MATERIAL}

The Supplementary Material for this article can be found online at: https://www.frontiersin.org/articles/10.3389/fpls.2021.717223/ full\#supplementary-material

Supplementary Table 1 | Selection of important metabolites, genes, and transcription factors that have been shown to be modified by different pathogens. 
Bailly, S., Jerkovic, V., Meuree, A., Timmermans, A., and Collin, S. (2009). Fate of key odorants in sauternes wines through aging. J. Agric. Food Chem. 57, 8557-8563. doi: 10.1021/jf901429d

Behr, M., Serchi, T., Cocco, E., Guignard, C., Sergeant, K., Renaut, J., et al. (2014). Description of the mechanisms underlying geosmin production in Penicillium expansum using proteomics. J. Proteome 96, 13-28. doi: 10.1016/j. jprot.2013.10.034

Bertazzon, N., Forte, V., Filippin, L., Causin, R., Maixner, M., and Angelini, E. (2017). Association between genetic variability and titre of grapevine pinot gris virus with disease symptoms. Plant Pathol. 66, 949-959. doi: 10.1111/ ppa.12639

Blanco-Ulate, B., Amrine, K. C., Collins, T. S., Rivero, R. M., Vicente, A. R., Morales-Cruz, A., et al. (2015). Developmental and metabolic plasticity of white-skinned grape berries in response to Botrytis cinerea during Noble rot. Plant Physiol. 169, 2422-2443. doi: 10.1104/pp.15.00852

Blanco-Ulate, B., Hopfer, H., Figueroa-Balderas, R., Ye, Z., Rivero, R. M., Albacete, A., et al. (2017). Red blotch disease alters grape berry development and metabolism by interfering with the transcriptional and hormonal regulation of ripening. J. Exp. Bot. 68, 1225-1238. doi: 10.1093/jxb/erw506

Bock, G., Benda, I., and Schreier, P. (1986). "Metabolism of linalool by Botrytis cinerea," in Biogeneration of Aromas. Vol. 317. ed. M. Joan Comstock (American Chemical Society), 243-253.

Boidron, J. N. (1978). Relation entre les substances terpéniques et la qualité du raisin (rôle de Botrytis cinerea). Ann. Technol. Agric. 27, 141-145.

Bois, B., Zito, S., and Calonnec, A. (2017). Climate vs grapevine pests and diseases worldwide: the first results of a global survey. OENO One 51, 133-139. doi: 10.20870/oeno-one.2017.51.2.1780

Bove, F., Savary, S., Willocquet, L., and Rossi, V. (2020). Simulation of potential epidemics of downy mildew of grapevine in different scenarios of disease conduciveness. Eur. J. Plant Pathol. 158, 599-614. doi: 10.1007/s10658-020-02085-8

Bragard, C., Dehnen-Schmutz, K., Gonthier, P., Jacques, M.-A., Jaques Miret, J. A., Justesen, A. F., et al. (2019). List of non-EU viruses and viroids of Cydonia mill., Fragaria L., malus mill., Prunus L., Pyrus L., Ribes L., Rubus L. and Vitis L. EFSA J. 17:e05501. doi: 10.2903/j.efsa.2019.5501

Breia, R., Conde, A., Conde, C., Fortes, A. M., Granell, A., and Gerós, H. (2020a). VvERD6113 is a grapevine sucrose transporter highly up-regulated in response to infection by Botrytis cinerea and Erysiphe necator. Plant Physiol. Biochem. 154, 508-516. doi: 10.1016/j.plaphy.2020.06.007

Breia, R., Conde, A., Pimentel, D., Conde, C., Fortes, A. M., Granell, A., et al. (2020b). VvSWEET7 is a mono- and disaccharide transporter up-regulated in response to Botrytis cinerea infection in grape berries. Front. Plant Sci. 10:1753. doi: 10.3389/fpls.2019.01753

Burbidge, C. A., Ford, C. M., Melino, V. J., Wong, D. C. J., Jia, Y., Jenkins, C. L. D., et al. (2021). Biosynthesis and cellular functions of tartaric (and ascorbic) acids in grapevines. Front. Plant Sci. 12:643024. doi: 10.3389/fpls.2021.643024

Calonnec, A., Cartolaro, P., Poupot, C., Dubourdieu, D., and Darriet, P. (2004). Effects of Uncinula necator on the yield and quality of grapes (Vitis vinifera) and wine. Plant Pathol. 53, 434-445. doi: 10.1111/j.0032-0862.2004.01016.x

Carbonell-Bejerano, P., Rodríguez, V., Hernáiz, S., Royo, C., Dal Santo, S., Pezzotti, M., et al. (2016). Reducing sampling bias in molecular studies of grapevine fruit ripening: transcriptomic assessment of the density sorting method. Theor. Exp. Plant Physiol. 28, 109-129. doi: 10.1007/s40626-016-0059-5

Chong, J., Piron, M. C., Meyer, S., Merdinoglu, D., Bertsch, C., and Mestre, P. (2014). The SWEET family of sugar transporters in grapevine: VvSWEET4 is involved in the interaction with Botrytis cinerea. J. Exp. Bot. 65, 6589-6601. doi: 10.1093/jxb/eru375

Cieniewicz, E. J., Qiu, W. P., Saldarelli, P., and Fuchs, M. (2020). Believing is seeing: lessons from emerging viruses in grapevine. J. Plant Pathol. 102, 619-632. doi: 10.1007/s42161-019-00484-3

Coelho, J., Almeida-Trapp, M., Pimentel, D., Soares, F., Reis, P., Rego, C., et al. (2019). The study of hormonal metabolism of Trincadeira and Syrah cultivars indicates new roles of salicylic acid, jasmonates, ABA and IAA during grape ripening and upon infection with Botrytis cinerea. Plant Sci. 283, 266-277. doi: 10.1016/j.plantsci.2019.01.024

Conde, C., Silva, P., Fontes, N., Dias, A. C. P., Tavares, R. M., Sousa, M. J., et al. (2007). Biochemical changes throughout grape berry development and fruit and wine quality. FoodReview 1, 1-22.

Cozzi, G., Paciolla, C., Haidukowski, M., De Leonardis, S., Mule, G., and Logrieco, A. (2013). Increase of Fumonisin B2 and Ochratoxin A production by black aspergillus species and oxidative stress in grape berries damaged by powdery mildew. J. Food Prot. 76, 2031-2036. doi: 10.4315/0362-028X. JFP-13-149

Cretazzo, E., Padilla, C., Carambula, C., Hita, I., Salmerón, E., and Cifre, J. (2010). Comparison of the effects of different virus infections on performance of three Majorcan grapevine cultivars in field conditions. Ann. Appl. Biol. 156, 1-12. doi: 10.1111/j.1744-7348.2009.00355.x

Darriet, P., Pons, M., Henry, R., Dumont, O., Findeling, V., Cartolaro, P., et al. (2002). Impact odorants contributing to the fungus type aroma from grape berries contaminated by powdery mildew (Uncinula necator); incidence of enzymatic activities of the yeast Saccharomyces cerevisiae. J. Agric. Food Chem. 50, 3277-3282. doi: 10.1021/jf011527d

Darriet, P., Pons, M., Lamy, S., and Dubourdieu, D. (2000). Identification and quantification of geosmin, an earthy odorant contaminating wines. J. Agric. Food Chem. 48, 4835-4838. doi: 10.1021/jf0007683

de Ferron, P., Thibon, C., Shinkaruk, S., Darriet, P., and Pons, A. (2020). Aromatic potential of Bordeaux grape cultivars: identification and assays on 4-oxononanoic acid, a $\gamma$-nonalactone precursor. J. Agric. Food Chem. 68, 13344-13352. doi: 10.1021/acs.jafc.0c04171

Debat, H., Luna, F., Moyano, S., Zavallo, D., Asurmendi, S., and Gomez-Talquenca, S. (2020). First report of grapevine pinot gris virus infecting grapevine in Argentina. J. Plant Pathol. 102:1321. doi: 10.1007/ s42161-020-00608-0

Dubernet, M., Ribereau-Gayon, P., Lerner, H. R., Harel, E., and Mayer, A. M. (1977). Purification and properties of laccase from Botrytis cinerea. Phytochemistry 16, 191-193. doi: 10.1016/S0031-9422(00)86783-7

Dubourdieu, D., Koh, K. H., Bertrand, A., and Ribéreau-Gayon, P. (1983). Mise en évidence d'une activité estérasique chez Botrytis cinerea. C. R. Acad. Sci. 296, 1025-1028. doi: 10.4314/jab.v64i1.88468

Fontaine, F., Pinto, C., Vallet, J., Clément, C., Gomes, A. C., and Spagnolo, A. (2016). The effects of grapevine trunk diseases (GTDs) on vine physiology. Eur. J. Plant Pathol. 144, 707-721. doi: 10.1007/s10658-015-0770-0

Francesca, S., Giosuè, S., Tubiello, F., Andrea, R., Rossi, V., Federico, S., et al. (2006). Downy mildew (Plasmopara viticola) epidemics on grapevine under climate change. Glob. Chang. Biol. 12, 1299-1307. doi: 10.1111/j.1365-2486.2006.01175.x

Fuchs, M. (2020). Grapevine viruses: a multitude of diverse species with simple but overall poorly adopted management solutions in the vineyard. J. Plant Pathol. 102, 643-653. doi: 10.1007/s42161-020-00579-2

Gadoury, D. M., Seem, R. C., Ficke, A., and Wilcox, W. F. (2003). Ontogenic resistance to powdery mildew in grape berries. Phytopathology 93, 547-555. doi: 10.1094/PHYTO.2003.93.5.547

Gadoury, D. M., Seem, R. C., Pearson, R. C., Wilcox, W. F., and Dunst, R. M. (2001). Effects of powdery mildew on vine growth, yield, and quality of concord grapes. Plant Dis. 85, 137-140. doi: 10.1094/PDIS.2001.85.2.137

Gentili, A., Prota, V., Moro, G., Schianchi, N., Lucca, E., Luigi, M., et al. (2017). Identification of grapevine pinot gris virus in Sardinia and Lazio (south and Central Italy). J. Plant Pathol. 99, 527-530. doi: 10.4454/jpp. v99i2.3872

Ghaffari, S., Reynard, J. S., and Rienth, M. (2020). Single berry sampling reveals new insights into transcriptomic reprogramming of grapevine ( $V$. vinifera) berries caused by leafroll virus infections. Sci. Rep. 10:12905. doi: 10.1038/ s41598-020-69779-1

Giampetruzzi, A., Roumi, V., Roberto, R., Malossini, U., Yoshikawa, N., La Notte, P., et al. (2012). A new grapevine virus discovered by deep sequencing of virus- and viroid-derived small RNAs in cv pinot gris. Virus Res. 163, 262-268. doi: 10.1016/j.virusres.2011.10.010

Gilardi, G., Chitarra, W., Moine, A., Mezzalama, M., Boccacci, P., Pugliese, M., et al. (2020). Biological and molecular interplay between two viruses and powdery and downy mildews in two grapevine cultivars. Hortic. Res. 7:188. doi: 10.1038/s41438-020-00413-x

Gindro, K., Alonso-Villaverde, V., Viret, O., Spring, J.-L., Marti, G., Wolfender, J.-L., et al. (2012a). "Stilbenes: biomarkers of grapevine resistance to disease of high relevance for agronomy, oenology and human health," in Plant Defence: Biological Control. eds. J. M. Mérillon and K. G. Ramawat (Dordrecht: Springer Netherlands), 25-54.

Gindro, K., Alonso-Villaverde, V., Voinesco, F., Spring, J. L., Viret, O., and Dubuis, P. H. (2012b). Susceptibility to downy mildew in grape clusters: new microscopical and biochemical insights. Plant Physiol. Biochem. 52, 140-146. doi: 10.1016/j.plaphy.2011.12.009 
Girardello, R. C., Cooper, M. L., Smith, R. J., Lerno, L. A., Bruce, R. C., Eridon, S., et al. (2019). Impact of grapevine red blotch disease on grape composition of Vitis vinifera cabernet sauvignon, merlot, and chardonnay. J. Agric. Food Chem. 67, 5496-5511. doi: 10.1021/acs.jafc.9b01125

Girardello, R. C., Rich, V., Smith, R. J., Brenneman, C., Heymann, H., and Oberholster, A. (2020). The impact of grapevine red blotch disease on Vitis vinifera L. chardonnay grape and wine composition and sensory attributes over three seasons. J. Sci. Food Agric. 100, 1436-1447. doi: 10.1002/jsfa.10147

Guidoni, S., Mannini, F., Ferrandino, A., Argamante, N., and Di Stefano, R. (1997). The effect of grapevine Leafroll and rugose wood sanitation on agronomic performance and berry and leaf phenolic content of a Nebbiolo clone (Vitis vinifera L.). Am. J. Enol. Vitic. 48, 438-442.

Hasanuzzaman, M., Nahar, K., Anee, T. I., and Fujita, M. (2017). Glutathione in plants: biosynthesis and physiological role in environmental stress tolerance. Physiol. Mol. Biol. Plants 23, 249-268. doi: 10.1007/s12298-017-0422-2

Kelloniemi, J., Trouvelot, S., Heloir, M. C., Simon, A., Dalmais, B., Frettinger, P., et al. (2015). Analysis of the molecular dialogue Between Gray Mold (Botrytis cinerea) and grapevine (Vitis vinifera) reveals a clear shift in Defense mechanisms During berry ripening. Mol. Plant-Microbe Interact. 28, 1167-1180. doi: 10.1094/MPMI-02-15-0039-R

Kennelly, M. M., Gadoury, D. M., Wilcox, W. F., Magarey, P. A., and Seem, R. C. (2005). Seasonal development of ontogenic resistance to downy mildew in grape berries and rachises. Phytopathology 95, 1445-1452. doi: 10.1094/ phyto-95-1445

Kikuchi, T., Kadota, S., Suehara, H., Nishi, A., Tsubaki, K., Yano, H., et al. (1983). Odorous metabolites of fungi, Chaetomium globosum KINZE ex FR. And Botrytis cinerea PERS. ex FR., and a blue-green alga, Phormidium tenue (MENEGHINI) GOMONT. Chem. Pharm. Bull. 31, 659-663. doi: $10.1248 / \mathrm{cpb} .31 .659$

Kobayashi, H., Takase, H., Suzuki, Y., Tanzawa, F., Takata, R., Fujita, K., et al. (2011). Environmental stress enhances biosynthesis of flavor precursors, S-3-(hexan-1-ol)-glutathione and S-3-(hexan-1-ol)-L-cysteine, in grapevine through glutathione S-transferase activation. J. Exp. Bot. 62, 1325-1336. doi: $10.1093 /$ jxb/erq376

Kuhn, N., Guan, L., Dai, Z. W., Wu, B.-H., Lauvergeat, V., Goms, E., et al. (2013). Berry ripening: recently heard through the grapevine. J. Exp. Bot. 65, 4543-4559. doi: 10.1093/jxb/ert395

Ky, I., Lorrain, B., Jourdes, M., Pasquier, G., Fermaud, M., Geny, L., et al. (2012). Assessment of grey mould (Botrytis cinerea) impact on phenolic and sensory quality of Bordeaux grapes, musts and wines for two consecutive vintages. Aust. J. Grape Wine Res. 18, 215-226. doi: 10.1111/j.1755-0238.2012.00191.x

La Guerche, S., Dauphin, B., Pons, M., Blancard, D., and Darriet, P. (2006). Characterization of some mushroom and earthy off-odors microbially induced by the development of rot on grapes. J. Agric. Food Chem. 54, 9193-9200. doi: 10.1021/jf0615294

La Guerche, S., De Senneville, L., Blancard, D., and Darriet, P. (2007). Impact of the Botrytis cinerea strain and metabolism on (-)-geosmin production by Penicillium expansum in grape juice. Antonie Van Leeuwenhoek 92, 331-341. doi: 10.1007/s10482-007-9161-7

Lecourieux, F., Kappel, C., Pieri, P., Charon, J., Pillet, J., Hilbert, G., et al. (2017). Dissecting the biochemical and transcriptomic effects of a locally applied heat treatment on developing cabernet sauvignon grape berries. Front. Plant Sci. 8:53. doi: 10.3389/fpls.2017.00053

Lin, J., Massonnet, M., and Cantu, D. (2019). The genetic basis of grape and wine aroma. Hortic. Res. 6:81. doi: 10.1038/s41438-019-0163-1

Lopez Pinar, A., Rauhut, D., Ruehl, E., and Buettner, A. (2016). Effects of Botrytis cinerea and Erysiphe necator fungi on the aroma character of grape must: A comparative approach. Food Chem. 207, 251-260. doi: 10.1016/j. foodchem.2016.03.110

Lopez Pinar, A., Rauhut, D., Ruehl, E., and Buettner, A. (2017a). Effects of bunch rot (Botrytis cinerea) and powdery mildew (Erysiphe necator) fungal diseases on wine aroma. Front. Chem. 5:20. doi: 10.3389/fchem.2017.00020

Lopez Pinar, A., Rauhut, D., Ruehl, E., and Buettner, A. (2017b). Quantification of the changes in potent wine odorants as induced by bunch rot (Botrytis cinerea) and powdery mildew (Erysiphe necator). Front. Chem. 5:57. doi: 10.3389/fchem.2017.00057

Lorrain, B., Ky, I., Pasquier, G., Jourdes, M., Dubrana, L. G., Geny, L., et al. (2012). Effect of esca disease on the phenolic and sensory attributes of cabernet sauvignon grapes, musts and wines. Aust. J. Grape Wine Res. 18, 64-72. doi: 10.1111/j.1755-0238.2011.00172.x

Lovato, A., Zenoni, S., Tornielli, G. B., Colombo, T., Vandelle, E., and Polverari, A. (2019a). Plant and fungus transcriptomic data from grapevine berries undergoing artificially-induced noble rot caused by Botrytis cinerea. Data Brief 25:104150. doi: 10.1016/j.dib.2019.104150

Lovato, A., Zenoni, S., Tornielli, G. B., Colombo, T., Vandelle, E., and Polverari, A. (2019b). Specific molecular interactions between Vitis vinifera and Botrytis cinerea are required for noble rot development in grape berries. Postharvest Biol. Technol. 156:110924. doi: 10.1016/j.postharvbio.2019.05.025

Maliogka, V. I., Martelli, G. P., Fuchs, M., and Katis, N. I. (2015). Control of viruses infecting grapevine. Adv. Virus Res. 91, 175-227. doi: 10.1016/bs. aivir.2014.11.002

Maree, H. J., Almeida, R. P. P., Bester, R., Chooi, K. M., Cohen, D., Dolja, V. V., et al. (2013). Grapevine leafroll-associated virus 3. Front. Microbiol. 4:82. doi: $10.3389 /$ fmicb.2013.00082

Martínez-Lüscher, J., Plank, C. M., Brillante, L., Cooper, M. L., Smith, R. J., Al-Rwahnih, M., et al. (2019). Grapevine red blotch virus may reduce carbon translocation leading to impaired grape berry ripening. J. Agric. Food Chem. 67, 2437-2448. doi: 10.1021/acs.jafc.8b05555

Massi, F., Torriani, S. F. F., Borghi, L., and Toffolatti, S. L. (2021). Fungicide resistance evolution and detection in plant pathogens: Plasmopara viticola as a case study. Microorganisms 9:119. doi: 10.3390/ microorganisms 9010119

Messmer, N., Bohnert, P., Schumacher, S., and Fuchs, R. (2021). Studies on the occurrence of viruses in planting material of grapevines in southwestern Germany. Viruses 13:248. doi: 10.3390/v13020248

Miklósy, É., and Kerényi, Z. (2004). Comparison of the volatile aroma components in noble rotted grape berries from two different locations of the Tokaj wine district in Hungary. Anal. Chim. Acta 513, 177-181. doi: 10.1016/j. aca.2003.11.087

Molitor, D., Baus, O., Hoffmann, L., and Beyer, M. (2016). Meteorological conditions determine the thermal-temporal position of the annual botrytis bunch rot epidemic on Vitis vinifera; L. cv. Riesling grapes. OENO One 50. doi: 10.20870/oeno-one.2016.50.4.36

Naidu, R. A., Maree, H. J., and Burger, J. T. (2015). Grapevine leafroll disease and associated viruses: a unique pathosystem. Annu. Rev. Phytopathol. 53, 613-634. doi: 10.1146/annurev-phyto-102313-045946

Naidu, R., Rowhani, A., Fuchs, M., Golino, D., and Martelli, G. P. (2014). Grapevine Leafroll: A complex viral disease affecting a high-value fruit crop. Plant Dis. 98, 1172-1185. doi: 10.1094/PDIS-08-13-0880-FE

Pallotta, U., Castellari, M., Piva, A., Baumes, R., and Bayonove, C. (1998). Effects of Botrytis cinerea on must composition of three Italian grape varietie. Die Wein Wissenschaft 53, 32-36.

Pereira, G. E., Padhi, E. M. T., Sudarshana, M. R., Fialho, F. B., Medina-Plaza, C., Girardello, R. C., et al. (2021). Impact of grapevine red blotch disease on primary and secondary metabolites in 'Cabernet Sauvignon' grape tissues. Food Chem. 342:128312. doi: 10.1016/j.foodchem.2020.128312

Perrone, I., Chitarra, W., Boccacci, P., and Gambino, G. (2017). Grapevinevirus-environment interactions: an intriguing puzzle to solve. New Phytol. 213, 983-987. doi: 10.1111/nph.14271

Piermattei, B., Piva, A., Casterllari, M., Arfelli, G., and Amatai., A. (1999). The phenolic composition of redgrapes and wines as influenced by Oidium tuckerideve-lopment. Vitis 38, 85-86.

Pimentel, D., Amaro, R., Erban, A., Mauri, N., Soares, F., Rego, C., et al. (2021). Transcriptional, hormonal, and metabolic changes in susceptible grape berries under powdery mildew infection. J. Exp. Bot. 72, 6544-6569. doi: $10.1093 / \mathrm{jxb} / \mathrm{erab} 258$

Poitou, X., Redon, P., Pons, A., Bruez, E., Delière, L., Marchal, A., et al. (2021). Methyl salicylate, a grape and wine chemical marker and sensory contributor in wines elaborated from grapes affected or not by cryptogamic diseases. Food Chem. 360:130120. doi: 10.1016/j.foodchem.2021.130120

Pons, A., Mouakka, N., Deliere, L., Crachereau, J. C., Davidou, L., Sauris, P., et al. (2018). Impact of Plasmopara viticola infection of merlot and cabernet sauvignon grapes on wine composition and flavor. Food Chem. 239, 102-110. doi: 10.1016/j.foodchem.2017.06.087

Pool, R., Pearson, R. C., Welser, M. J., Lakso, A. N., and Seem, R. (1984). Influence of powdery mildew on yield and growth of rosette grapevines. Plant Dis. 68, 590-593. 
Rantsiou, K., Giacosa, S., Pugliese, M., Englezos, V., Ferrocino, I., Río Segade, S., et al. (2020). Impact of chemical and alternative fungicides applied to grapevine cr Nebbiolo on microbial ecology and chemical-physical grape characteristics at harvest. Front. Plant Sci. 11:700. doi: 10.3389/fpls.2020.00700

Raski, D. J., Goheen, A. C., Lider, L. A., and Meredith, C. P. (1983). Strategies against grapevine fanleaf virus and its nematode vector. Plant Dis. 67, 335-339. doi: 10.1094/PD-67-335

Reineke, A., and Thiéry, D. (2016). Grapevine insect pests and their natural enemies in the age of global warming. J. Pest. Sci. 89, 313-328. doi: 10.1007/ s10340-016-0761-8

Renault-Spilmont, A.-S., Sevin Preyre, A.-F., Jérémy, G., Beuve, M., Alliaume, A., Marais, A., et al. (2018). Occurrence of Grapevine Pinot gris virus (GPGV) and Grapevine Leaf Mottling and Deformation (GLMD) syndrome in France: genetic diversity and field monitoring in diverse viticulture areas. Conference: ICVG 2018At: Santiago, Chile.

Repetto, O., Bertazzon, N., Rosso, M. D., Miotti, L., Flamini, R., Angelini, E., et al. (2012). Low susceptibility of grapevine infected by GLRaV-3 to late Plasmopara viticola infections: towards understanding the phenomenon. Physiol. Mol. Plant Pathol. 79, 55-63. doi: 10.1016/j.pmpp.2012.04.001

Reynard, J. S., Brodard, J., Dubuis, N., Zufferey, V., Schumpp, O., Schaerer, S., et al. (2018). Grapevine red blotch virus: absence in Swiss vineyards and analysis of potential detrimental effect on Viticultural performance. Plant Dis. 102, 651-655. doi: 10.1094/PDIS-07-17-1069-RE

Riaz, S., Tenscher, A. C., Ramming, D. W., and Walker, M. A. (2011). Using a limited mapping strategy to identify major QTLs for resistance to grapevine powdery mildew (Erysiphe necator) and their use in marker-assisted breeding. Theor. Appl. Genet. 122, 1059-1073. doi: 10.1007/s00122-010-1511-6

Rienth, M., Crovadore, M., Ghaffari, S., and Lefort, F. (2019a). Oregano essential oil vapour prevents Plasmopora viticola infection in grapevine (Vitis Vinifera) by triggering autoimmune metabolic pathway. PLoS One 14:e0222854. doi: 10.1371/journal.pone.0222854

Rienth, M., Ghaffari, S., and Reynard, J. S. (2019b). "Impact of grapevine leafroll virus infections on vine physiology and the berry transcriptome." in Paper presented at the GiESCO Thessaloniki, Greece.

Rienth, M., Torregrosa, L., Kelly, M. T., Luchaire, N., Pellegrino, A., Grimplet, J., et al. (2014a). Is transcriptomic regulation of berry development more important at night than During the day? PLoS One 9:e88844. doi: 10.1371/ journal.pone.0088844

Rienth, M., Torregrosa, L., Luchaire, N., Chatbanyong, R., Lecourieux, D., Kelly, M., et al. (2014b). Day and night heat stress trigger different transcriptomic responses in green and ripening grapevine (vitis vinifera) fruit. BMC Plant Biol. 14:108. doi: 10.1186/1471-2229-14-108

Rienth, M., Vigneron, N., Darriet, P., Sweetman, C., Burbidge, C., Bonghi, C., et al. (2021). Grape berry secondary metabolites and their modulation by abiotic factors in a climate change scenario-a review. Front. Plant Sci. doi: 10.3389/fpls.2021.643258 [Epub ahead of print].

Ruiz-García, A. B., and Olmos, A. (2017). First report of grapevine pinot gris virus in grapevine in Spain. Plant Dis. 101:1070. doi: 10.1094/PDIS-12-16-1858-PDN

Rumbaugh, A. C., Girardello, R. C., Cooper, M. L., Plank, C., Kurtural, S. K., and Oberholster, A. (2021). Impact of rootstock and season on red blotch disease expression in cabernet sauvignon (V. vinifera). Plan. Theory 10:1583. doi: 10.3390/plants10081583

Rupnik-Cigoj, M., Jež-Krebelj, A., Castellarin, S. D., Trošt, K., Sivilotti, P., and Pompe-Novak, M. (2018). Grapevine fanleaf virus affects grape (Vitis vinifera) berry anthocyanin content via the transcriptional regulation of anthocyanin biosynthetic genes. Funct. Plant Biol. 45, 771-782. doi: 10.1071/FP18014

Salinari, F., Giosuè, S., Rossi, V., Tubiello, F. N., Rosenzweig, C., and Gullino, M. L. (2007). Downy mildew outbreaks on grapevine under climate change: elaboration and application of an empirical-statistical model*. EPPO Bulletin 37, 317-326. doi: 10.1111/j.1365-2338.2007.01126.x

Santos, J. A., Fraga, H., Malheiro, A. C., Moutinho-Pereira, J., Dinis, L.-T., Correia, C., et al. (2020). A review of the potential climate change impacts and adaptation options for European Viticultu. Appl. Sci. 10:3092. doi: 10.3390/app10093092

Sarrazin, E., Dubourdieu, D., and Darriet, P. (2007). Characterization of keyaroma compounds of botrytized wines, influence of grape botrytization. Food Chem. 103, 536-545. doi: 10.1016/j.foodchem.2006.08.026

Schreier, P., Drawert, F., Kerenyi, Z., and Junker, A. (1976). GLC-massspectrometrical investigation of the volatile components of wines. VI. Aroma compounds of Tokaj aszu wines. (a) Neutral compounds (author's transl). Z. Lebensm. Unters. Forsch. 161, 249-258. doi: 10.1007/bf01105811

Shahood, R., Torregrosa, L., Savoi, S., and Romieu, C. (2020). First quantitative assessment of growth, sugar accumulation and malate breakdown in a single ripening berry. OENO One 54, 1077-1092. doi: 10.20870/oenoone.2020.54.4.3787

Shimazu, Y., Uehara, M., and Watanabe, M. (1984). Decomposition of 1-tartaric and 1-malic acids in grape must by Botrytis cinerea. Agric. Biol. Chem. 48, 1565-1573. doi: 10.1080/00021369.1984.10866360

Silva, G., Lecourt, J., Clover, G. R. G., and Seal, S. (2017). First report of grapevine fanleaf virus infecting grapevine in the United Kingdom. New Disease Rep. 36:9. doi: 10.5197/j.2044-0588.2017.036.009

Stamatopoulos, P., Frérot, E., Tempère, S., Pons, A., and Darriet, P. (2014). Identification of a new lactone contributing to overripe Orange aroma in Bordeaux dessert wines via perceptual interaction phenomena. J. Agric. Food Chem. 62, 2469-2478. doi: 10.1021/jf405397c

Stamatopoulos, P., Thibon, C., Redon, P., and Darriet, P. (2018). "Influence de la botrytisation dans la genèse des composés associés à des nuances typiques de larôme des vins liquoreux de pourriture noble." in Paper presented at the Eno2015, 10th International Symposium Enology. Bordeaux: Vigne Vin Publications Internationales.

Steel, C. C., Blackman, J. W., and Schmidtke, L. M. (2013). Grapevine bunch rots: impacts on wine composition, quality, and potential procedures for the removal of wine faults. J. Agric. Food Chem. 61, 5189-5206. doi: 10.1021/ jf400641r

Stummer, B., Francis, I. L., Markides, A., and Scott, E. S. (2003). The effect of powdery mildew infection of grape berries on juice and wine composition and on sensory properties of chardonnay wines. Aust. J. Grape Wine Res. 9, 28-39. doi: 10.1111/j.1755-0238.2003.tb00229.x

Stummer, B. E., Francis, I. L., Zanker, T., Lattey, K. A., and Scott., E. S., (2005). Effects of powdery mildew on the sensory properties and composition of chardonnay juice and wine when grape sugar ripeness is standardised. Aust. J. Grape Wine Res. 11, 66-76. doi: 10.1111/ j.1755-0238.2005.tb00280.x

Sudarshana, M. R., Perry, K. L., and Fuchs, M. F. (2015). Grapevine red blotchassociated virus, an emerging threat to the grapevine industry. Phytopathology 105, 1026-1032. doi: 10.1094/PHYTO-12-14-0369-FI

Terrier, N., Glissant, D., Grimplet, J., Barrieu, F., Abbal, P., Couture, C., et al. (2005). Isogene specific oligo arrays reveal multifaceted changes in gene expression during grape berry development. Planta 222, 832-847. doi: 10.1007/ s00425-005-0017-y

Thibon, C., Cluzet, S., Merillon, J. M., Darriet, P., and Dubourdieu, D. (2011). 3-Sulfanylhexanol precursor biogenesis in grapevine cells: the stimulating effect of Botrytis cinerea. J. Agric. Food Chem. 59, 1344-1351. doi: 10.1021/ jf103915y

Thibon, C., Dubourdieu, D., Darriet, P., and Tominaga, T. (2009). Impact of noble rot on the aroma precursor of 3-sulfanylhexanol content in Vitis vinifera L. cv sauvignon blanc and Semillon grape juice. Food Chem. 114, 1359-1364. doi: 10.1016/j.foodchem.2008.11.016

Toffolatti, S. L., De Lorenzis, G., Brilli, M., Moser, M., Shariati, V., Tavakol, E., et al. (2020). Novel aspects on the interaction Between grapevine and Plasmopara viticola: dual-RNA-Seq analysis highlights gene expression dynamics in the pathogen and the plant during the battle for infection. Gene 11:261. doi: $10.3390 /$ genes 11030261

Tominaga, T., Peyrot des Gachons, C., and Dubourdieu, D. (1998). A new type of flavor precursors in Vitis vinifera L. cv. Sauvignon blanc: S-cysteine conjugates. J. Agric. Food Chem. 46, 5215-5219. doi: 10.1021/ jf980481u

Tosi, E., Fedrizzi, B., Azzolini, M., Finato, F., Simonato, B., and Zapparoli, G. (2012). Effects of noble rot on must composition and aroma profile of Amarone wine produced by the traditional grape withering protocol. Food Chem. 130, 370-375. doi: 10.1016/j.foodchem.2011.07.053

Vega, A., Gutierrez, R. A., Pena-Neira, A., Cramer, G. R., and Arce-Johnson, P. (2011). Compatible GLRaV-3 viral infections affect berry ripening decreasing sugar accumulation and anthocyanin biosynthesis in Vitis vinifera. Plant Mol. Biol. 77, 261-274. doi: 10.1007/s11103-011-9807-8

Velasco, L., Bota, J., Montero, R., and Cretazzo, E. (2014). Differences of three Ampeloviruses' multiplication in plant may explain their incidences in vineyards. Plant Dis. 98, 395-400. doi: 10.1094/PDIS-04-13-0433-RE 
Vondras, A. M., Lerno, L., Massonnet, M., Minio, A., Rowhani, A., Liang, D., et al. (2021). Rootstock influences the effect of grapevine leafroll-associated viruses on berry development and metabolism via abscisic acid signalling. Mol. Plant Pathol. 22, 984-1005. doi: 10.1111/mpp.13077

Walker, R. P., Bonghi, C., Varotto, S., Battistelli, A., Burbidge, C. A., Castellarin, S. D., et al. (2021). Sucrose metabolism and transport in grapevines, with emphasis on berries and leaves, and insights gained from a cross-species comparison. Int. J. Mol. Sci. 22:7794. doi: 10.3390/ijms22157794

Wanner, P., and Tressl, R. (1998). Purification and characterization of two enone reductases from Saccharomyces cerevisiae. Eur. J. Biochem. 255, 271-278. doi: 10.1046/j.1432-1327.1998.2550271.x

Zini, E., Dolzani, C., Stefanini, M., Gratl, V., Bettinelli, P., Nicolini, D., et al. (2019). R-loci arrangement versus downy and powdery mildew resistance level: A Vitis hybrid survey. Int. J. Mol. Sci. 20:3526. doi: 10.3390/ijms20143526

Zito, S., Caffarra, A., Richard, Y., Castel, T., and Bois, B. (2018). Climate change and vine protection: the case of mildews management in Burgundy. E3S Web Conf. 50:01006. doi: 10.1051/e3sconf/20185001006
Conflict of Interest: The authors declare that the research was conducted in the absence of any commercial or financial relationships that could be construed as a potential conflict of interest.

Publisher's Note: All claims expressed in this article are solely those of the authors and do not necessarily represent those of their affiliated organizations, or those of the publisher, the editors and the reviewers. Any product that may be evaluated in this article, or claim that may be made by its manufacturer, is not guaranteed or endorsed by the publisher.

Copyright (C) 2021 Rienth, Vigneron, Walker, Castellarin, Sweetman, Burbidge, Bonghi, Famiani and Darriet. This is an open-access article distributed under the terms of the Creative Commons Attribution License (CC BY). The use, distribution or reproduction in other forums is permitted, provided the original author(s) and the copyright owner(s) are credited and that the original publication in this journal is cited, in accordance with accepted academic practice. No use, distribution or reproduction is permitted which does not comply with these terms. 